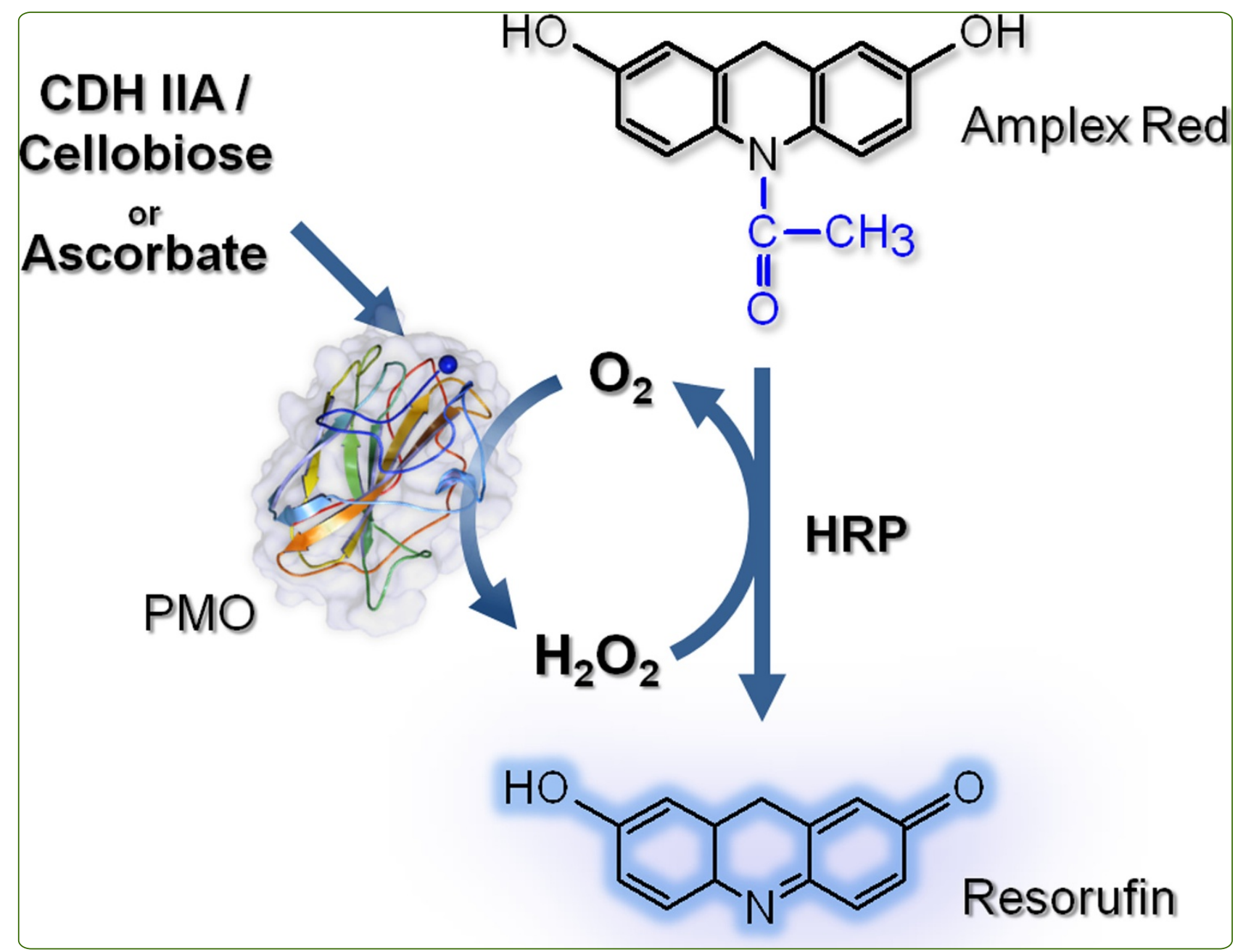

Production of four Neurospora crassa lytic polysaccharide monooxygenases in Pichia pastoris monitored by a fluorimetric assay

Kittl et al. 


\title{
Production of four Neurospora crassa lytic polysaccharide monooxygenases in Pichia pastoris monitored by a fluorimetric assay
}

\author{
Roman Kittl, Daniel Kracher, Daniel Burgstaller, Dietmar Haltrich and Roland Ludwig*
}

\begin{abstract}
Background: Recent studies demonstrate that enzymes from the glycosyl hydrolase family 61 (GH61) show lytic polysaccharide monooxygenase (PMO) activity. Together with cellobiose dehydrogenase $(\mathrm{CDH})$ an enzymatic system capable of oxidative cellulose cleavage is formed, which increases the efficiency of cellulases and put PMOs at focus of biofuel research. Large amounts of purified PMOs, which are difficult to obtain from the native fungal producers, are needed to study their reaction kinetics, structure and industrial application. In addition, a fast and robust enzymatic assay is necessary to monitor enzyme production and purification.

Results: Four pmo genes from Neurospora crassa were expressed in P. pastoris under control of the AOX1 promoter. High yields were obtained for the glycosylated gene products PMO-01867, PMO-02916 and PMO-08760 (>300 $\left.\mathrm{mg} \mathrm{L}^{-1}\right)$, whereas the yield of non-glycosylated PMO-03328 was moderate $\left(\sim 45 \mathrm{mg} \mathrm{L}^{-1}\right)$. The production and purification of all four enzymes was specifically followed by a newly developed, fast assay based on a side reaction of PMO: the production of $\mathrm{H}_{2} \mathrm{O}_{2}$ in the presence of reductants. While ascorbate is a suitable reductant for homogeneous PMO preparations, fermentation samples require the specific electron donor CDH.
\end{abstract}

Conclusions: P. pastoris is a high performing expression host for N. crassa PMOs. The pmo genes under control of the native signal sequence are correctly processed and active. The novel CDH-based enzyme assay allows fast determination of PMO activity in fermentation samples and is robust against interfering matrix components.

\section{Background}

Hydrolysis is still a major cost factor in the production of second-generation biofuels from lignocellulosic biomass, considering the costs of currently available enzyme mixtures. Until recently, only hydrolytic enzymes were thought to play a role in the degradation of recalcitrant cellulose and hemicelluloses to fermentable sugars. The finding that enzymes from glycosyl hydrolase family 61 (GH61) in combination with the flavocytochrome cellobiose dehydrogenase $(\mathrm{CDH})$ enhance the action of hydrolytic enzymes added a new dimension to the classical concept of cellulose degradation, as recently reviewed by Horn et al. [1]. These copper-dependent enzymes were shown to cleave cellulose by an oxidative mechanism provided that reduction equivalents from

\footnotetext{
* Correspondence: roland.ludwig@boku.ac.at
Department of Food Sciences and Technology, Food Biotechnology
Laboratory, BOKU - University of Natural Resources and Life Sciences,

* Correspondence: roland.ludwig@boku.ac.at
Department of Food Sciences and Technology, Food Biotechnology
Laboratory, BOKU - University of Natural Resources and Life Sciences,

* Correspondence: roland.ludwig@boku.ac.at
Department of Food Sciences and Technology, Food Biotechnology
Laboratory, BOKU - University of Natural Resources and Life Sciences, Muthgasse 18, Vienna 1190, Austria
}

(c) 2012 Kittl et al.; licensee BioMed Central Ltd. This is an Open Access article distributed under the terms of the Creative Commons Attribution License (http://creativecommons.org/licenses/by/2.0), which permits unrestricted use, distribution, and reproduction in any medium, provided the original work is properly cited.
CDH or low molecular weight reducing agents (e.g. asconfirmed activity have been termed polysaccharide monooxygenases (PMOs) [3] or, to indicate the reaction mechanism more specificly, lytic PMOs [1]. Recently, it was shown that enzymes of the structurally similar CBM33 family are also capable of cleaving cellulose. Unlike lytic PMOs they are mainly found in bacteria, but also in other eukaryotes [5].

The $\mathrm{CDH} / \mathrm{PMO}$ system was shown to improve the degradation of cellulose in combination with cellulases in several studies [2-4,6,7]. In the proposed reaction mechanism $\mathrm{CDH}$ donates an electron via its cytochrome domain to the type-2 copper in the PMO active site. There, oxygen is partially reduced and attacks the pyranose ring of the glucose moieties at the $\mathrm{C}-1$ (class-1 PMOs) or C-4 (class-2 PMOs) position, thereby destabilizing the adjacent glycosidic bond and breaking it by an elimination reaction [3,8]. The occurrence of gh61 (pmo) 
genes has been confirmed in many cellulolytic fungi. In some genomes, gh61 genes even outnumber cellulase genes [9-11]. It remains to be elucidated whether all of these encoded enzymes have PMO activity, but their large number emphasizes the importance of oxidative cellulose cleavage. In the cellulolytic ascomycete Neurospora crassa, 2 cdh genes and 14 pmo genes are present. When the fungus is grown on Miscanthus one $c d h$ gene and 8 pmo genes are upregulated [11]. In our study the expression of four of these pmo genes in Pichia pastoris is investigated. Only few examples of heterologous expression of pmo genes are hitherto known. A PMO from Thermoascus aurantiacus was expressed in Trichoderma reesei by Novozymes [6], and three PMOs (from Phanerochaete chrysosporium, Sporotrichum thermophile and Aspergillus kawachii) were produced in P. pastoris with the $\alpha$-factor signal sequence for secretion [7,12,13]. Although the expressions and purifications were successful, none of these studies reported production or purification yields. One reason for that is certainly the lack of a fast and robust assay for PMO activity. The assays currently used to determine PMO activity are based on a lengthy incubation of the PMO together with $\mathrm{CDH}$ or a reductant such as ascorbate and the polymeric cellulosic substrates Avicel, phosphoric acid swollen cellulose (PASC), carboxymethyl cellulose (CMC) or nanofibrillated cellulose at elevated temperatures $\left(37^{\circ} \mathrm{C}-50^{\circ} \mathrm{C}\right)$ for several hours or up to three days. Subsequently, the reaction products are analyzed by MALDI-TOF/MS, HPAEC or LC/MS [3,5,6,12-14]. While these timeconsuming and labor-intensive assays are a good choice for investigating the reaction mechanism and substrate specificity, they are of little use for monitoring fermentation processes or the progress of a purification procedure. The proposed reaction mechanism [3] points to the possibility that hydrogen peroxide is generated as a byproduct of a futile side reaction, which might occur in the absence of cellulose as a substrate. Li et al. [15] found that peroxide can be modeled well in an electron density at the coordination site of the type- 2 copper in $N$. crassa PMO-3 [GenBank: NCU07898]. In this work, we measure the oxygen reducing side reactivity of PMOs by quantifying the formation of hydrogen peroxide. Based on this observation a fast and robust enzymatic assay for PMO activity was developed and tested on the expression and purification of four PMOs from $N$. crassa.

\section{Results and discussion}

\section{Polysaccharide monooxygenase activity assay}

This newly developed assay is based on an easily accessible side-reaction of PMO. The reduction of $\mathrm{O}_{2}$ to $\mathrm{H}_{2} \mathrm{O}_{2}$ by $\mathrm{PMO}$ has not been reported so far and is not the proposed in vivo function, but is thought to occur as a futile side-reaction, especially in the absence of the natural substrate cellulose. By adding different amounts of PMO to the assay mixture we could prove that the formation of $\mathrm{H}_{2} \mathrm{O}_{2}$ is directly proportional to the PMO concentration. The formation of $\mathrm{H}_{2} \mathrm{O}_{2}$ depends on the availability of a suitable reductant for the PMO type- 2 copper center. In this study, ascorbate or the proposed natural interaction partner of PMOs - $\mathrm{CDH}$ together with cellobiose - was used as reductant/electron donor. The proposed reaction scheme is given in Figure 1.

$\mathrm{H}_{2} \mathrm{O}_{2}$ formed in this reaction was selectively and sensitively detected with the Amplex Red/horseradish peroxidase reaction [16]. The stability of the resorufin fluorescence was tested for $40 \mathrm{~min}$ and shown to be stable much longer than the assay time of $10 \mathrm{~min}$ (Additional file 1). The fluorimetric signal response is linear for a range from $0.1-2 \mu \mathrm{M} \mathrm{H}_{2} \mathrm{O}_{2}$ with a slight offset from background fluorescence $\left(y=a \cdot x+y_{0}\right)$. It can be very well approximated by a 3 parameter logarithmic function $\left(\mathrm{y}=\mathrm{y}_{0}+\mathrm{a} \cdot \ln \left(\mathrm{x}-\mathrm{x}_{0}\right)\right)$ up to a PMO concentration of $5 \mu \mathrm{M}\left(\mathrm{R}^{2}=0.99\right)$ (Figure $\left.2 \mathrm{~A}, \mathrm{~B}\right)$. The direct proportionality between the concentration of added PMO and measured $\mathrm{H}_{2} \mathrm{O}_{2}$ was observed for the ascorbate- as well as for the $\mathrm{CDH}$-driven assay. A linear range was found for up to $1.2 \mathrm{U} \mathrm{L}^{-1}$ of PMO activity when using ascorbate and $1.8 \mathrm{U} \mathrm{L}^{-1}$ when using $\mathrm{CDH}$ (Figure $2 \mathrm{C}-\mathrm{F}$ ). The background activity caused by the formation of $\mathrm{H}_{2} \mathrm{O}_{2}$ by autooxidation of ascorbic acid as well as by the weak $\mathrm{H}_{2} \mathrm{O}_{2}$ producing activity of $\mathrm{CDH}$ is significant (Table 1 ). Therefore, activities of blank reactions without PMOs were subtracted from the overall activities measured in the presence of PMOs. If possible, the fluorescence should be continuously measured (no end-point determination) to increase the correctness and precision of the measurement (Figure 3).

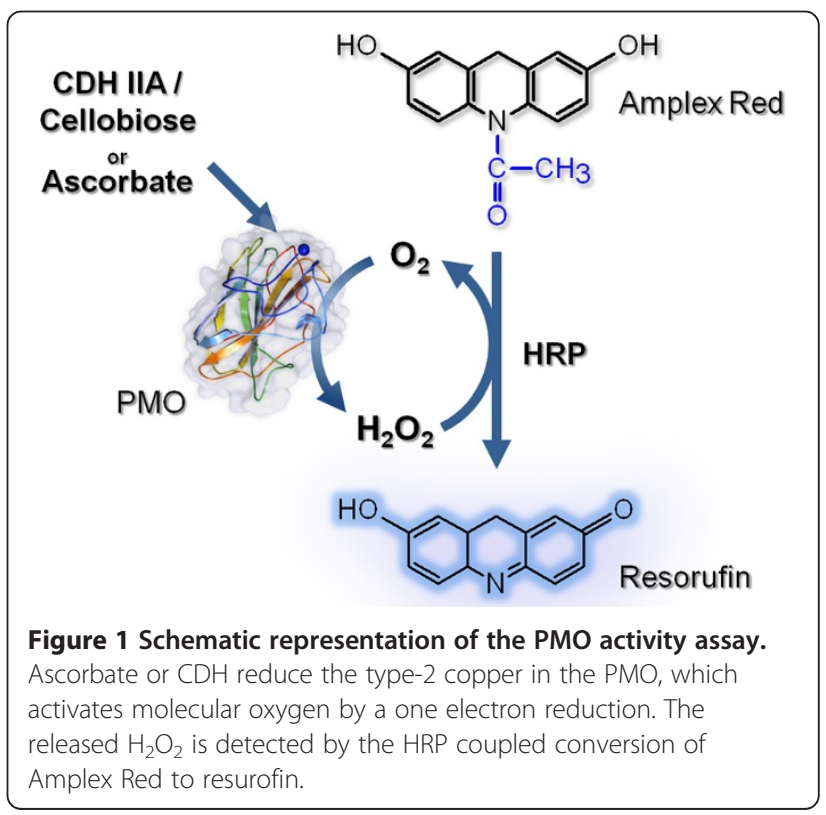



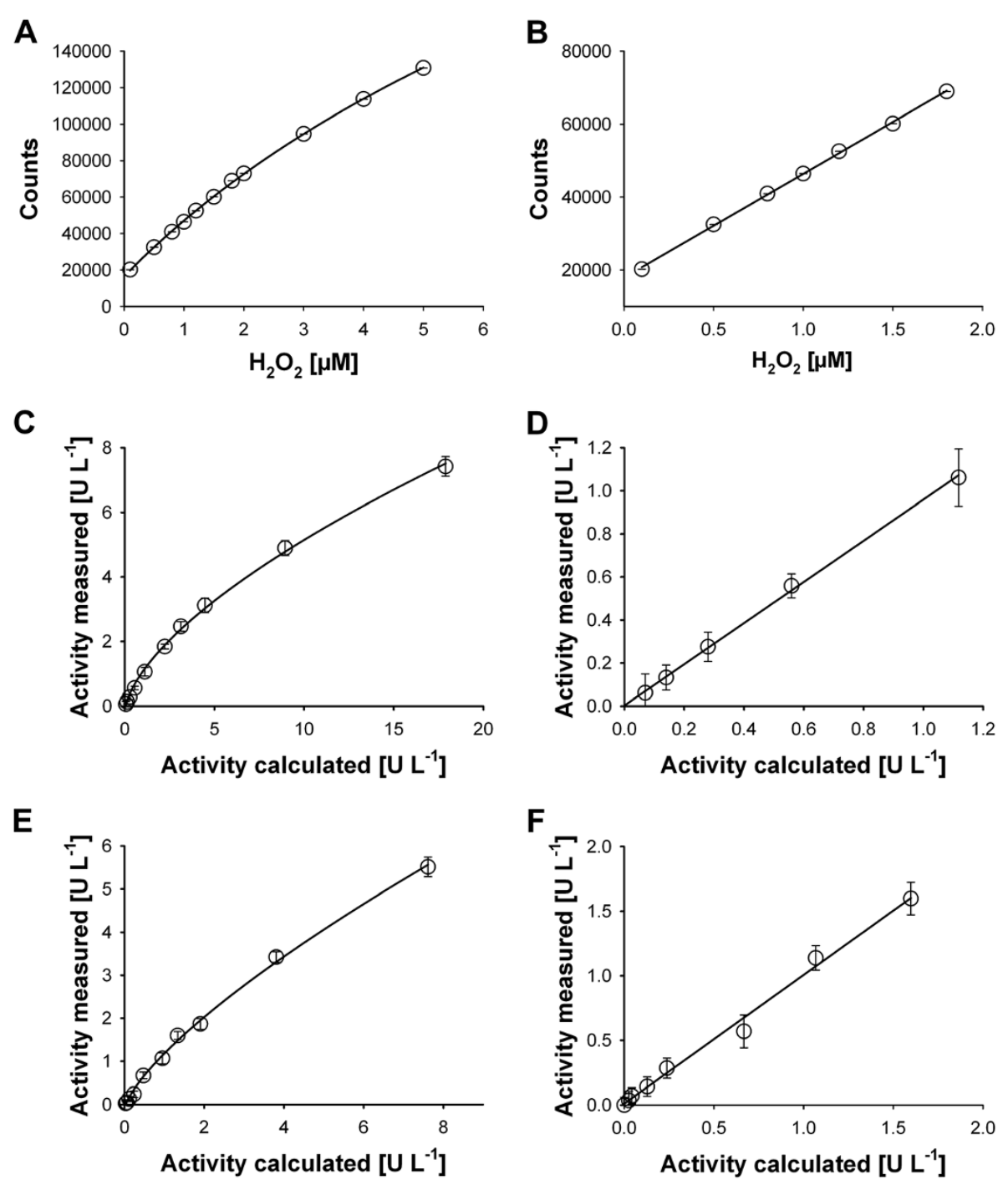

Figure 2 Calibration and response curves. (A) $\mathrm{H}_{2} \mathrm{O}_{2}$ full concentration range; (B) $\mathrm{H}_{2} \mathrm{O}_{2}$ linear concentration range; (C) Ascorbate-driven assay: full concentration range fitted by a 2 parameter power function $\left(y=a \cdot x^{\mathrm{b}}\right) ;(\mathbf{D})$ Ascorbate-driven assay: linear concentration range $(y=a \cdot x) ;(\mathbf{E})$ $\mathrm{CDH}$-driven assay: full concentration range fitted by a 2 parameter power function; $(\mathbf{F}) \mathrm{CDH}$-driven assay: linear concentration range. Error bars indicate standard deviations calculated from five repetitions.

We employed CDH IIA from $N$. crassa for this assay, which is the major $\mathrm{CDH}$ in the $N$. crassa secretome [17] and which was recombinantly produced in P. pastoris [18]. A possible direct interaction of PMO with cellobiose, the electron donor of $\mathrm{CDH}$, was tested by replacing cellobiose by lactose. Lactose interacts almost equally well with $\mathrm{NcCDH}$ IIA [18] and did not alter the peroxide formation by PMOs.

PMO activity in fermentation samples can only be determined with the $\mathrm{CDH}$-driven assay, since the strong reducing agent ascorbate interacts unspecifically with other oxidases present in the P. pastoris culture supernatant (e.g. alcohol oxidase 1) and media components, generating a strong background signal. To exclude the effects of media components (e.g. copper ions) on the $\mathrm{CDH}$-based assay, sample aliquots were additionally centrifuged in mini-spin columns with $10-\mathrm{kDa}$ cut-off, and the blank activity of the permeate was subtracted. A possible interference by proteins in the $P$. pastoris culture supernatant on the assay was examined by measuring background activities of culture supernatant and its permeate (10 kDa cut-off) of two similar fermentations of a $P$. pastoris strain without PMO. The media components in the permeate increase the blank activity significantly (1.6 times). The increase of the background $\mathrm{H}_{2} \mathrm{O}_{2}$ production by the culture supernatant is 1.7 fold (Additional file 2). This shows that compounds with a molecular mass above $10 \mathrm{kDa}$ (proteins) have also a 
Table 1 Contribution of background activities of CDH IIA and ascorbic acid, respectively, to the total activity measured with various concentrations of PMO (PMO-02916)

\begin{tabular}{|c|c|c|c|c|}
\hline Assay & $\frac{\text { PMO concentration }}{\left[\mathrm{mg} \mathrm{mL}^{-1}\right]}$ & $\frac{\mathrm{H}_{2} \mathrm{O}_{2} \text { production }}{\left[\mu \mathrm{mol} \mathrm{L}^{-1} \mathrm{~min}^{-1}\right]}$ & $\frac{\text { PMO activity }}{\left[\mu \mathrm{mol} \mathrm{L}^{-1} \mathrm{~min}^{-1}\right]}$ & $\frac{\text { Background activity }}{[\%]}$ \\
\hline \multirow[t]{5}{*}{ Ascorbate } & 2.87 & $5.39 \pm 0.23$ & 4.90 & 9.1 \\
\hline & 1.43 & $3.61 \pm 0.22$ & 3.12 & 13 \\
\hline & 0.72 & $2.34 \pm 0.05$ & 1.85 & 21 \\
\hline & 0.18 & $1.05 \pm 0.01$ & 0.56 & 47 \\
\hline & 0.02 & $0.63 \pm 0.02$ & 0.14 & 78 \\
\hline Blank & 0 & $0.49 \pm 0.02$ & 0 & 0 \\
\hline \multirow[t]{5}{*}{ CDH IIA } & 5.74 & $6.21 \pm 0.22$ & 5.51 & 11 \\
\hline & 1.43 & $2.57 \pm 0.11$ & 1.87 & 27 \\
\hline & 0.72 & $1.77 \pm 0.11$ & 1.07 & 40 \\
\hline & 0.18 & $0.94 \pm 0.05$ & 0.24 & 74 \\
\hline & 0.02 & $0.74 \pm 0.05$ & 0.04 & 94 \\
\hline Blank & 0 & $0.70 \pm 0.04$ & 0 & 0 \\
\hline
\end{tabular}

limited effect. The estimated error for using the permeate as blank experiment instead of the full sample matrix is $8-10 \%$, which seems acceptable for the monitoring of PMO activity in fermentations.

\section{Recombinant production of PMO-01867, PMO-02916, PMO-03328 and PMO-08760}

Four pmo genes from $N$. crassa were selected for this study based on the phylogenetic analysis of Li et al. [15] and Sygmund et al. [18]. The closely related genes NCU08760 and NCU01867 were chosen, since both include a family 1 cellulose-binding module (CBM) and are classified as type-1 PMOs [15]. A transcriptome analysis of $N$. crassa showed that the transcription level of NCU08760 increased 107-fold when grown on Miscanthus compared to minimal medium, whereas the transcription level of NCU01867 remained almost unchanged [11]. Additionally, native NCU08760 was purified from $N$. crassa previously and its function as polysaccharide monooxygenase was confirmed $[3,8]$. Another type-1 PMO [GenBank:NCU03328] was chosen as an example for a PMO without CBM that is also induced, but to a minor extent (26-fold). NCU02916 is classified as a type-2 PMO, has a CBM and is induced during growth on Miscanthus (85-fold). The cDNAs of these four GH61 enzymes were commercially synthesized including their native signal sequences and were codon-optimized for expression in P. pastoris. The genes were cloned into the Pichia expression vector pPICZ $\alpha$ A without the $\alpha$-factor sequence and transformed into $P$. pastoris X33 cells. Transformants were checked for correct insertion of the pmo genes and replacement of the aox 1 gene in the Pichia genome by PCR with the standard primers $5^{\prime} \mathrm{AOX}$ and $3^{\prime} \mathrm{AOX}$. A positive clone of
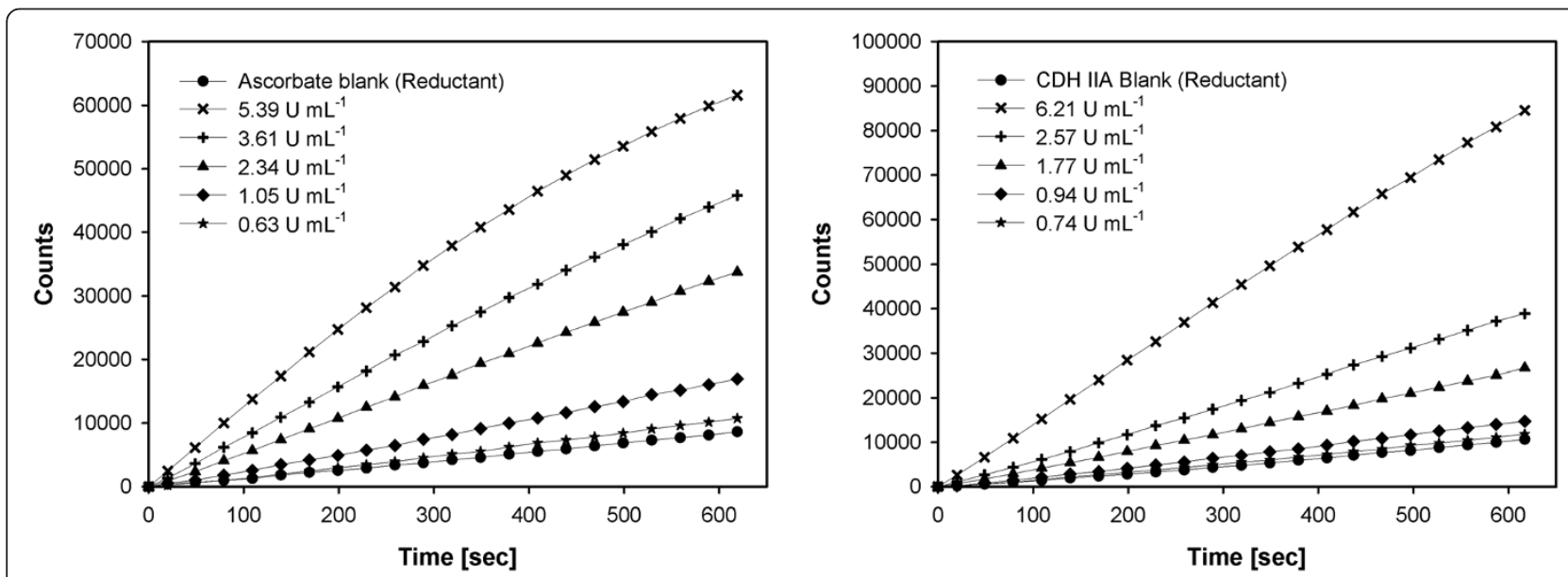

Figure 3 Background activities of reductants and total activities in the presence of various concentrations of PMO (PMO-02916). Assays were performed under standard conditions. 
each transformation was then chosen for enzyme production in a 7-L bioreactor. These cultivations were monitored for wet biomass, extracellular protein concentration, and PMO formation both by the PMO activity assay (Figure 4) and SDS-PAGE (Figure 5). After the batch and glycerol fed-batch phases for biomass buildup, the wet biomass concentration in the fermentation of PMO-01867, PMO-02916, PMO-03328 and PMO08760 reached 349, 290, 371 and $342 \mathrm{~g} \mathrm{~L}^{-1}$, respectively. At this stage, no PMO activity could be detected and extracellular protein concentrations were very low $\left(<0.1 \mathrm{~g} \mathrm{~L}^{-1}\right)$. Cell growth slowed down considerably after induction with methanol, and expression of the target proteins could be observed both by an increase in extracellular protein concentration and PMO activity. All cultivations were well comparable with respect to biomass formation, and cell densities ranging from 388 to $447 \mathrm{~g} \mathrm{~L}^{-1}$ wet biomass were reached at the time of harvest. After around 120 hours of cultivation (PMO01867, PMO-03328 and PMO-08760) or 145 hours (PMO-02916) of cultivation the extracellular protein concentrations reached $1.57,1.82,1.33$ and $2.76 \mathrm{~g} \mathrm{~L}^{-1}$, respectively. PMO activities in the culture supernatants, however, showed that the expression levels of the target proteins varied considerably between PMO-01867 $\left(0.46 \pm 0.05 \mathrm{U} \mathrm{L}^{-1}\right)$, PMO-03328 $\left(0.72 \pm 0.07 \mathrm{U} \mathrm{L}^{-1}\right)$, PMO-08760 (1.46 $\left.\pm 0.05 \mathrm{U} \mathrm{L}^{-1}\right)$ and PMO-02916 $\left(4.46 \pm 0.04 \mathrm{U} \mathrm{L}^{-1}\right)$. Accordingly, the fraction of PMO in total secreted protein was highest for PMO-02916 (28.5\%), followed by PMO-08760 (25.7\%) and PMO01867 (19.9\%) as calculated from the respective specific activities of these enzymes. Only $2.5 \%$ of the extracellular protein accounted for the small, non-glycosylated PMO-03328. These expression levels correlate well with the PMO bands seen on SDS-PAGE (Figure 5). The data for PMO activity and extracellular protein concentration at the time of harvest are summarized in Table 2. The fact that all four PMO enzymes were secreted and active confirms that $P$. pastoris is able to correctly process various $N$. crassa signal peptides. This strategy of using the native signal sequences is simpler than using the $\alpha$-factor and subsequent proteolytic cleavage to guarantee the native $\mathrm{N}$-terminal sequence of PMO [12]. The presence of the first N-terminal amino acid, a histidine, is essential since it participates in the coordination of the copper ion. An additional amino acid at the $\mathrm{N}$-terminus or a loss of this histidine would render the protein inactive $[4,15]$.

\section{Purification of recombinant PMOs}

$N$. crassa PMOs were purified to homogeneity in a standardized three-step chromatographic purification procedure (Table 3) with the exception of PMO-02916, which already showed a single band on SDS-PAGE after
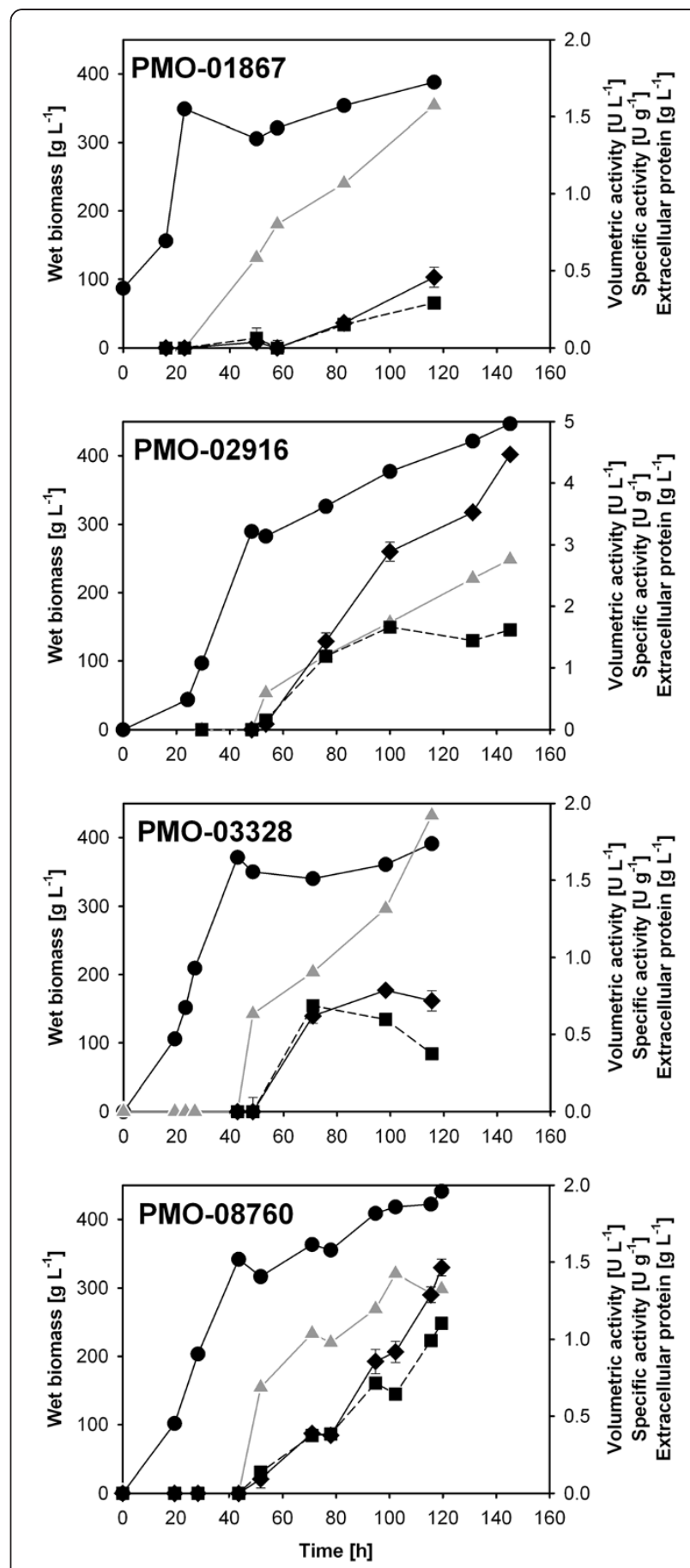

Figure 4 Production of PMOs in $\boldsymbol{P}$. pastoris. Circles, wet biomass; triangles, extracellular protein concentration; diamonds, activity; squares, specific activity.

two steps. The first step - hydrophobic interaction chromatography (HIC) - was used as a capturing step and increased the specific activity of the three glycosylated PMOs only around two-fold in combination with low yields especially of PMO-08760 and PMO-02916. The reason for this is incomplete binding of the PMOs even 


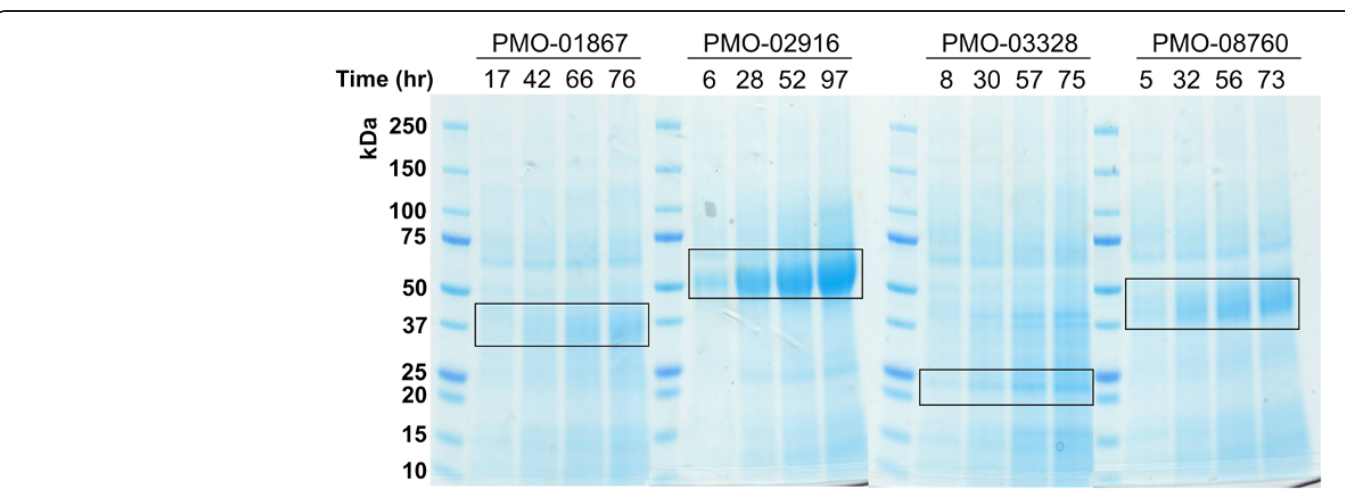

Figure 5 SDS-PAGE of PMO fermentation samples after induction (methanol induction $=0 \mathrm{~h}$ ). The formation of PMO is visible by increasing band strength (boxes).

when applying high ammonium sulphate saturation and smearing during the elution. In contrast, the specific activity of non-glycosylated PMO-03328 was increased almost 7 -fold with a yield of $76 \%$. An obvious difference between the glycosylated and the non-glycosylated PMOs was the weaker binding of PMO-03328 to the HIC resin. While PMO-01867, PMO-02916 and PMO08760 eluted at a conductivity of 53,42 and $57 \mathrm{mS} \mathrm{cm}^{-1}$, respectively, PMO-03328 already eluted at $72 \mathrm{mS} \mathrm{cm}^{-1}$. The second step - anion exchange chromatography (AIEX) - took advantage of the very weak binding of all four PMOs to the selected resin. The conductivity of all PMO pools after HIC was reduced to $<1.4 \mathrm{mS} \mathrm{cm}^{-1}$ and the $\mathrm{pH}$ was increased to 8.0 before application of the protein samples to the column. These conditions ensured the binding of a vast majority of yeast proteins while PMO was found in the flow-through. This product flow-through purification proved to be quick and efficient for all 4 PMOs. Subsequent gel filtration was used as polishing step and resulted in homogeneous protein preparations (Figure 6). Strict pooling of only the purest fractions resulted in the low overall yields. The purification procedure can certainly be improved by PMO specific modifications to this general, non-optimized purification procedure.

The specific activities of the pure enzymes differ according to the method used to determine the protein concentration. When using the absorbance at $280 \mathrm{~nm}$ and the calculated molecular absorption coefficient, the specific activities are lower by a factor of 1.54 (PMO01867), 2.1 (PMO-02916), 0.93 (PMO-03328) and 1.99 (PMO-08760) compared to the Bradford method for protein quantification with a BSA standard curve. This obviously reflects the inaccuracy of the Bradford assay for glycosylated proteins.

PMOs were incubated with cellulose and $\mathrm{CDH} /$ lactose as electron donor in an experiment to examine the lytic activity of the purified proteins on cellulose. HPLC analysis of the supernatant of the reaction mix showed the formation of cello-oligosaccharides in contrast to the blank reactions, where the reducing system $\mathrm{CDH} /$ lactose or the PMOs were omitted (Figure 7). The sample peaks could not fully be assigned to the peaks of the standard, because no standard for oxidized cello-oligosaccharides was available to us. However, the comparison with the negative controls and with results of similar experiments $[3-5,12]$ not only shows that the purified proteins indeed are lytic PMOs, it also emphasized the importance of $\mathrm{CDH}$ as electron donor for the cellulolytic function.

\section{Molecular properties}

Molecular masses were determined by SDS-PAGE (Figure 6). It is clearly visible that three of the four proteins are heavily glycosylated resulting in diffuse bands of considerably larger size than calculated from their amino acid sequences (Table 4). PMO-03328, the only PMO investigated in this study without a CBM is not glycosylated and shows a sharp band of the calculated

Table 2 Fermentation of PMO enzymes

\begin{tabular}{|c|c|c|c|c|c|c|}
\hline Enzyme & $\frac{\text { Harvest time }}{[\mathrm{h}]}$ & $\frac{\text { Wet biomass }}{\left[\mathrm{g} \mathrm{L}^{-1}\right]}$ & $\frac{\text { Protein conc. }}{\left[\mathrm{g} \mathrm{L}^{-1}\right]}$ & $\frac{\text { Vol. act. }}{\left[\mathrm{U} \mathrm{L}^{-1}\right]}$ & $\frac{\text { Spec. act. }}{\left[\mathrm{U} \mathrm{g}^{-1}\right]}$ & $\frac{\text { TTP } \text { conc. }^{a}}{\left[g^{-1}\right]}$ \\
\hline PMO-01867 & 116.5 & 388 & 1.57 & 0.46 & 0.38 & 0.31 \\
\hline PMO-02916 & 145.0 & 447 & 2.76 & 4.46 & 1.59 & 0.79 \\
\hline PMO-03328 & 115.5 & 391 & 1.82 & 0.72 & 0.39 & 0.05 \\
\hline PMO-08760 & 119.5 & 441 & 1.33 & 1.46 & 1.05 & 0.34 \\
\hline
\end{tabular}

${ }^{a}$ Total Target Protein concentration was calculated from the total protein concentration using the specific activity of the purified PMO. 
Table 3 Purification scheme of recombinant PMO enzymes

\begin{tabular}{|c|c|c|c|c|c|}
\hline Purification step & Total protein $^{\mathrm{a}}[\mathrm{g}]$ & Total activity [U] & Specific Activity $\left[\mathrm{U} \mathrm{g}^{-1}\right]$ & Purification [-fold] & Yield [\%] \\
\hline \multicolumn{6}{|l|}{ PMO-01867 } \\
\hline Culture supernatant ( $2.5 \mathrm{~L}$ ) & 3.935 & 1.48 & 0.38 & 1 & 100 \\
\hline Phenyl Sepharose & 0.536 & 0.39 & 0.74 & 2.0 & 27 \\
\hline Q-Source & 0.211 & 0.25 & 1.18 & 3.2 & 17 \\
\hline Gel filtration & 0.060 & 0.12 & 1.91 & 5.1 & 7.8 \\
\hline \multicolumn{6}{|l|}{ PMO-02916 } \\
\hline Culture supernatant (2.1 L) & 5.800 & 9.21 & 1.59 & 1 & 100 \\
\hline Phenyl Sepharose & 0.334 & 1.10 & 3.28 & 2.1 & 12 \\
\hline Q-Source & 0.140 & 0.78 & 5.57 & 3.5 & 8 \\
\hline \multicolumn{6}{|l|}{ PMO-03328 } \\
\hline Culture supernatant (2.9 L) & 5.275 & 2.08 & 0.39 & 1 & 100 \\
\hline Phenyl Sepharose & 0.235 & 1.57 & 6.70 & 17.0 & 76 \\
\hline Q-Source & 0.074 & 0.70 & 9.52 & 24.1 & 34 \\
\hline Gel filtration & 0.007 & 0.11 & 15.76 & 39.9 & 5.4 \\
\hline \multicolumn{6}{|l|}{ PMO-08760 } \\
\hline Culture supernatant (2.3 L) & 3.052 & 3.19 & 1.05 & 1 & 100 \\
\hline Phenyl Sepharose & 0.158 & 0.30 & 1.87 & 1.8 & 9 \\
\hline Q-Source & 0.047 & 0.12 & 2.54 & 2.4 & 4 \\
\hline Gel filtration & 0.005 & 0.02 & 4.08 & 3.9 & 0.6 \\
\hline
\end{tabular}

size $(23.7 \pm 0.6 \mathrm{kDa})$. PMO-02916 is the largest protein with $57.5 \pm 0.8 \mathrm{kDa}$ and is $40.4 \%$ glycosylated, PMO01867 and PMO-08760 (molecular masses of $39.6 \pm$ $0.7 \mathrm{kDa}$ and $41.4 \pm 0.4 \mathrm{kDa})$ are glycosylated to a lesser

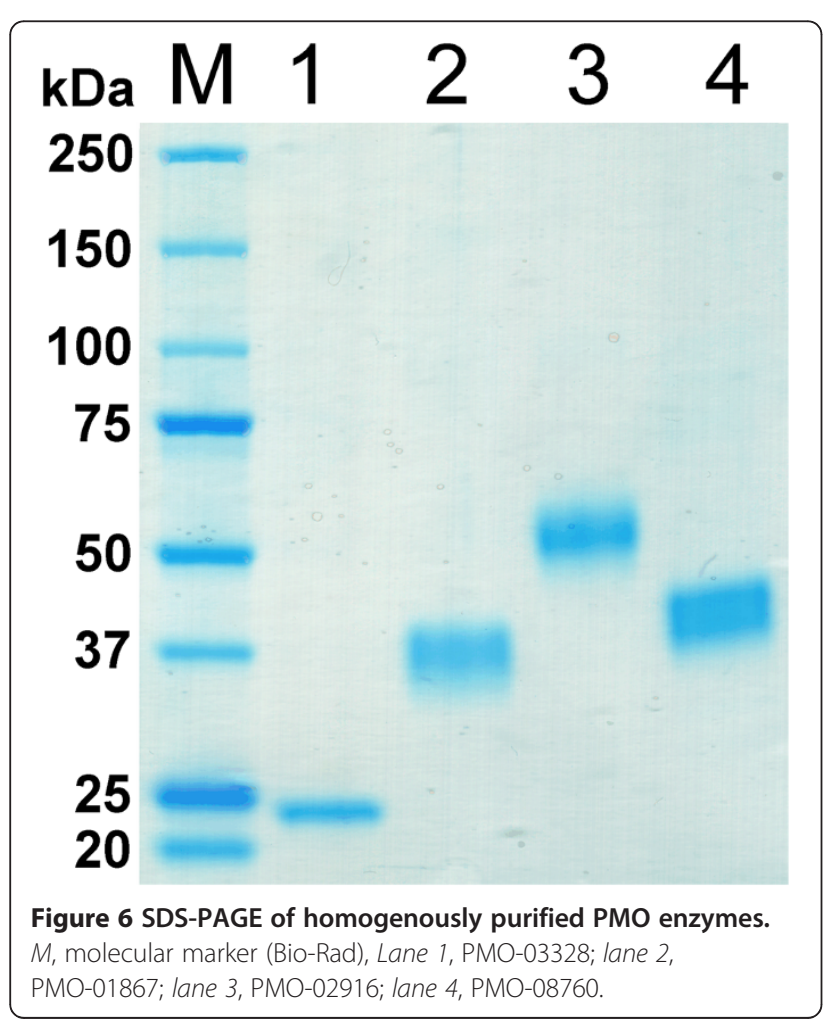

extent, $17.5 \%$ and $22.2 \%$, respectively. The size of PMO08760 expressed in $P$. pastoris is very similar to the size of the protein from its native source $N$. crassa [3], suggesting a similar extent of glycosylation and no hyperglycosylation by the yeast. Deglycosylation with PNGase $F$ under denaturing conditions had no visible effect on the appearance of the proteins on SDS-PAGE (data not shown), which has also been observed for other PMOs expressed in yeast $[7,13]$. PMO-02916 was the only investigated enzyme showing two $\mathrm{N}$-glycosylation sequons (Table 4), and only prolonged deglycosylation with $\mathrm{N}$-glycosidase $\mathrm{F}$ and $\alpha$-mannosidase showed a decrease of its mass [18]; no N-glycosylation sites were predicted for PMO-01867 and PMO-08760. The three glycosylated PMOs show O-glycosylation sites, and since no loss of molecular mass was observed after PNGase treatment under denaturing conditions, we conclude that the glycosylation of the PMOs must be O-glycosylation, presumably at the Ser/Thr-rich linker connecting the enzyme to the C-terminal CBM [7]. The amino acid sequences of the PMOs with highlighted signal peptides, putative $\mathrm{N}$ - and $\mathrm{O}$-glycosylation sites and CBMs are presented in Additional file 3.

The UV/VIS spectra of the purified PMOs (Figure 8) show peaks characteristic for a type- 2 copper at around $620 \mathrm{~nm}$. [19,20]. The absorbance is much weaker than that of a type-1 copper center, but clearly visible at high PMO concentration. The peaks vanished after reduction with ascorbate. The molar absorption coefficients and 

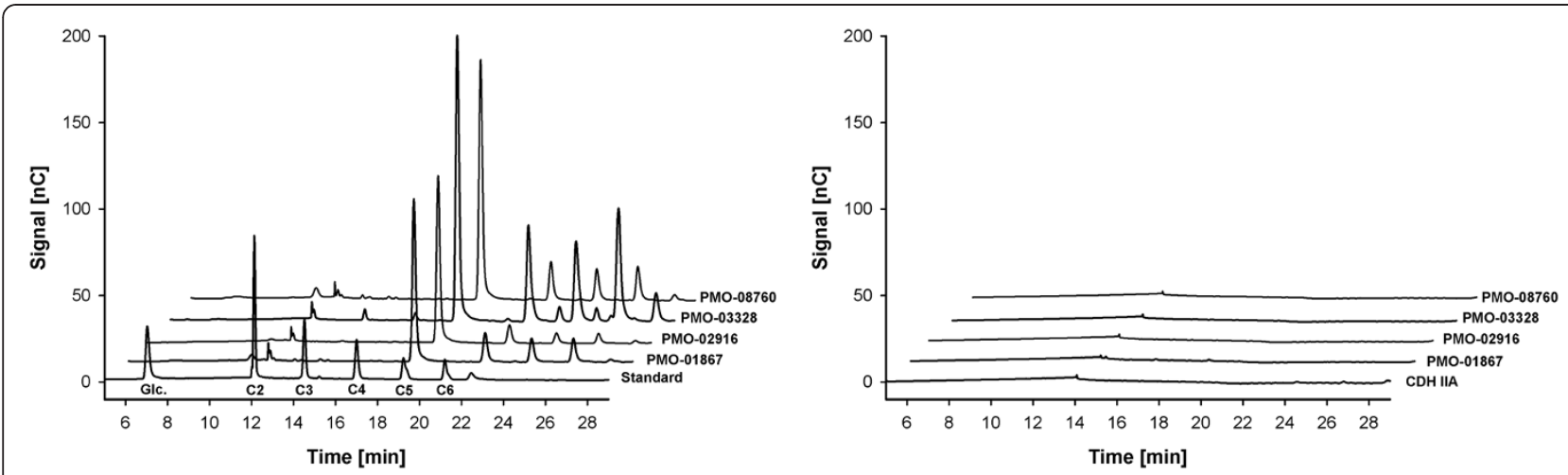

Figure 7 HPLC chromatograms of PMOs incubated with cellulose and CDH and blank experiments without CDH. Standards: Glc., glucose; C2, cellobiose; C3, cellotriose; C4, cellotetraose; C5, cellopentaose; C6, cellohexaose.

the Reinheitszahl (RZ) value for each PMO are presented in Table 5 . The stability of the PMO enzymes was investigated by differential scanning calorimetry (DSC). The transition midpoint temperatures were roughly similar for all four proteins with 66.9, 63.0, 68.9 and $67.9^{\circ} \mathrm{C}$ for PMO-01867, PMO-02916, PMO-03328 and PMO-08760, respectively (Additional file 4). Thaw/freeze stability was also determined by three cycles of freezing in liquid nitrogen and thawing at room temperature. No loss of activity was observed.

The specific activities for the $\mathrm{H}_{2} \mathrm{O}_{2}$ side reaction of the PMOs were determined for CDH IIA as well as for ascorbate as reducing agent (Table 6). When using ascorbate these activities were remarkably similar for the three glycosylated PMOs with four to five $\mathrm{U} \mathrm{g}^{-1}$ while PMO-03328 exhibited a three-fold higher activity. A similar picture was found for the assay with CDH IIA, however with more variation ranging from $1.07 \pm 0.13 \mathrm{U}$ $\mathrm{g}^{-1}$ (PMO-01867) to $15.46 \pm 0.97 \mathrm{U} \mathrm{g}^{-1}$ for PMO-03328. These results could be a measure for varying affinity of the respective PMO for CDH IIA as electron donor. The much higher specific activity of PMO-03328 is partly owing to the lower enzyme mass and maybe to a higher $\mathrm{H}_{2} \mathrm{O}_{2}$ production rate, not necessarily reflecting higher PMO activity.

\section{Conclusions}

P. pastoris was found to be a suitable expression host for glycosylated and non-glycosylated $N$. crassa PMO enzymes. A further advantage of this host is the correct processing of the $N$. crassa signal sequences of PMOs. This feature is especially important when considering that the active site of PMOs contains the N-terminal histidine. The PMO enzymes expressed in this study reduce oxygen and show typical type-2 copper absorption spectra, which supports the finding that these enzymes are in fact copper-containing PMOs. The newly developed $\mathrm{CDH}$-driven activity assay allows fast PMO activity measurements in fermentation samples and is robust against interfering matrix components. With an easy assay for the target protein available, optimization of fermentation and purification conditions will be greatly simplified and should substantially improve the yields. Additionally, it allows the establishment of a highthroughput screening for improved activity enabling for example a screening for better producing $P$. pastoris clones. The second assay using ascorbate as reducing agent provides a tool to measure PMO activity independently from the interaction between PMO and its electron donor $\mathrm{CDH}$, but it is too prone to interference to be used in crude enzyme samples such as fermentation media. Recombinant production of PMO enzymes should enable the formulation of more efficient, costeffective enzyme solutions for biofuel production from lignocellulosic biomass.

\section{Methods}

\section{Chemicals and microorganisms}

All chemicals were of the highest purity grade available and were purchased from Sigma-Aldrich unless stated otherwise.

Table 4 Molecular masses and glycosylation of PMO enzymes

\begin{tabular}{|c|c|c|c|c|c|c|}
\hline \multirow[t]{2}{*}{ Enzyme } & \multirow{2}{*}{$\frac{\text { SDS-PAGE }}{[\mathrm{kDa}]}$} & \multirow{2}{*}{$\frac{\text { Calculated }}{[\mathrm{kDa}]}$} & \multirow{2}{*}{$\frac{\text { Glycan mass }}{[\mathrm{kDa}]}$} & \multirow{2}{*}{$\frac{\text { Glycan mass }}{[\%]}$} & \multicolumn{2}{|c|}{ Putative glycosyl. sites } \\
\hline & & & & & O-Glyc. & $N$-Glyc. \\
\hline PMO-01867 & $39.6 \pm 0.7$ & 32.7 & 6.9 & 17.5 & 5 & 0 \\
\hline PMO-02916 & $57.5 \pm 0.8$ & 34.3 & 23.2 & 40.4 & 27 & 2 \\
\hline PMO-03328 & $23.7 \pm 0.6$ & 23.2 & 0.0 & 0.0 & 5 & 0 \\
\hline PMO-08760 & $41.4 \pm 0.4$ & 32.2 & 9.2 & 22.2 & 16 & 0 \\
\hline
\end{tabular}



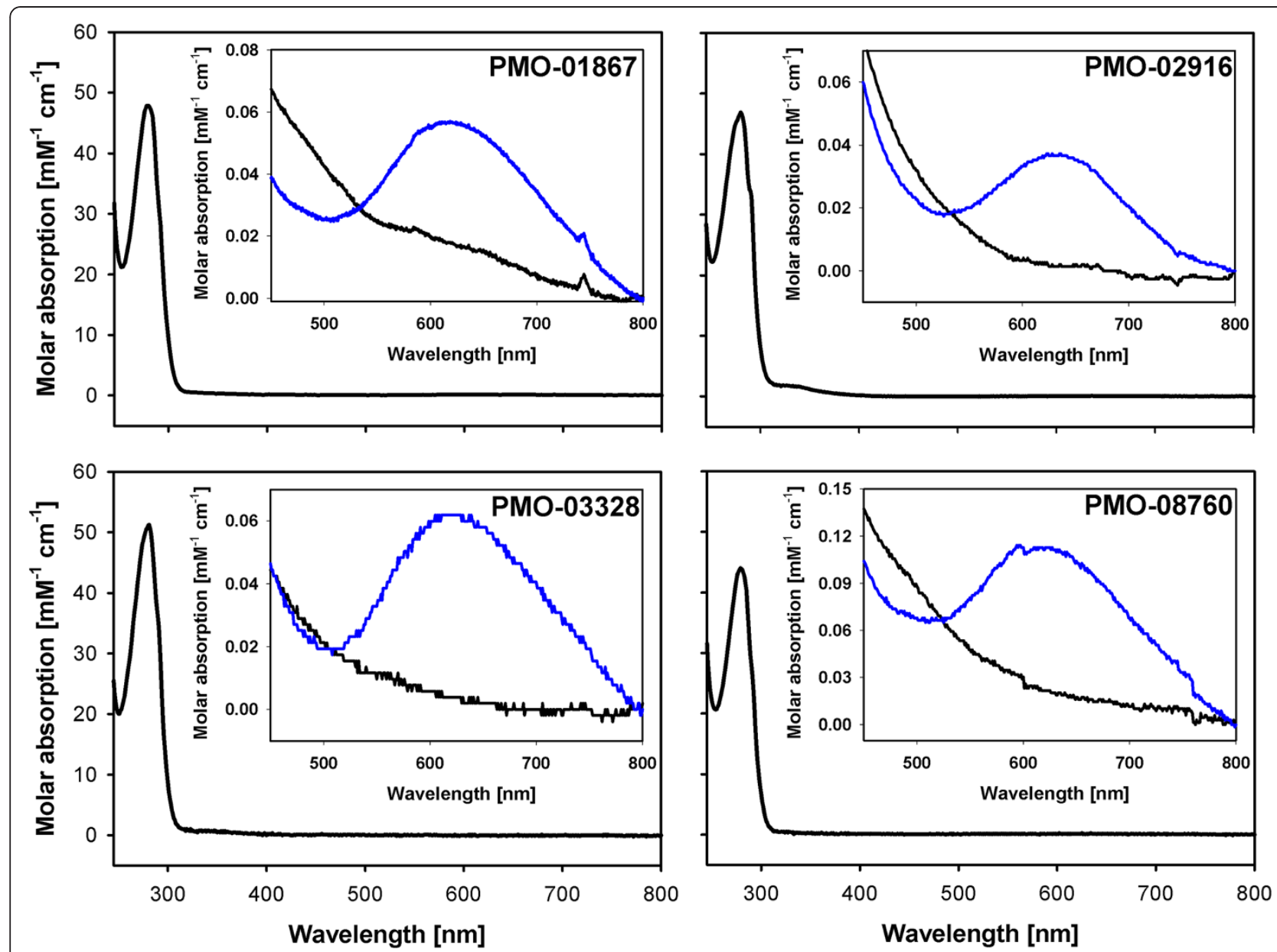

Figure 8 Spectra of PMOs. The weak absorption of the type-2 copper center is only visible in the inset. The small peaks around $615-650 \mathrm{~nm}$ disappear after reduction with ascorbate. Data for PMO-02916 was taken from Sygmund et al. [18].

Amplex Red (10-acetyl-3,7-dihydroxyphenoxazine) was purchased from VWR. Restriction endonucleases and T4 DNA ligase were obtained from Fermentas and were used as recommended by the manufacturer. Nucleic acid amplifications were done employing GoTAQ DNA Polymerase (Promega), dNTP mix, oligonucleotide primers (HVD Life Sciences, Vienna, Austria) and a C-1000 thermocycler (Bio-Rad Laboratories). E. coli strain DH5 $\alpha$ (Invitrogen) was used for subcloning. The gene coding for a PMO enzyme from N. crassa (GenBank:NCU02916,

Table 5 Spectral properties of investigated PMO enzymes

\begin{tabular}{|c|c|c|c|c|}
\hline Enzyme & $\frac{\varepsilon_{280}}{\left[\mathrm{mM}^{-1} \mathrm{~cm}^{-1}\right]}$ & $\frac{\lambda}{[\mathrm{nm}]}$ & $\frac{\varepsilon_{\text {type-2-Cu }}}{\left[\mathrm{mM}^{-1} \mathrm{~cm}^{-1}\right]}$ & $\frac{\mathrm{RZ} \text { value }}{\left[\varepsilon_{280} / \varepsilon_{\text {type-2-Cu}}\right]}$ \\
\hline PMO-02916 & 46.91 & 630 & 0.037 & 1270 \\
\hline PMO-03328 & 51.13 & 620 & 0.062 & 830 \\
\hline PMO-01867 & 47.87 & 620 & 0.057 & 840 \\
\hline PMO-08760 & 43.86 & 615 & 0.113 & 390 \\
\hline
\end{tabular}

gh61-3 [21]) has been previously expressed and purified by Sygmund et al. [18]. To simplify the denomination and also prevent confusion caused by the newly discovered polysaccharide monooxygenase function, we suggest to name this enzyme PMO-02916 on the basis of its GenBank number, and the other PMOs accordingly PMO01867 (GenBank:NCU01867, gh61-10 [22], PMO-03328 (GenBank:NCU03328, gh61-6 [21]), and PMO-08760 (GenBank:NCU08760, gh61-5 [21]). The N. crassa genes encoding the PMO enzymes were codon-optimized for

Table 6 Specific activities of PMO enzymes

\begin{tabular}{lcc}
\hline Enzyme & \multicolumn{2}{c}{ Reductant/Specific activity [U g $\left.{ }^{-1}\right]$} \\
\cline { 2 - 3 } & CDH IIA & Ascorbate \\
\hline PMO-01867 & $1.07 \pm 0.13$ & $4.00 \pm 0.18$ \\
\hline PMO-02916 & $1.82 \pm 0.04$ & $4.47 \pm 0.15$ \\
\hline PMO-03328 & $15.46 \pm 0.97$ & $12.08 \pm 0.67$ \\
\hline PMO-08760 & $1.53 \pm 0.19$ & $4.84 \pm 0.13$ \\
\hline
\end{tabular}


expression in P. pastoris (Additional file 5) and commercially synthesized by Invitrogen including their native signal sequences. $P$. pastoris strain $\mathrm{X}-33$ and the vector pPICZ $\alpha$ A are components of the Pichia Easy Select Expression System from Invitrogen. CDH IIA was produced and purified as previously reported [18].

\section{Amplex Red/horseradish peroxidase assay}

The oxygen reactivity of PMOs was measured by a time resolved quantification of $\mathrm{H}_{2} \mathrm{O}_{2}$ formation in 96-well plates (total volume of $200 \mu \mathrm{L}$ ) using a Perkin Elmer EnSpire Multimode plate reader. All reactions were performed in $100 \mathrm{mM}$ sodium phosphate buffer, $\mathrm{pH} 6.0$ at $22^{\circ} \mathrm{C}$. Based on preliminary studies ascorbate and $\mathrm{CDH}$ were used in concentrations of $30 \mu \mathrm{M}$ and $0.3 \mu \mathrm{M}$ $\left(0.025 \mathrm{mg} \mathrm{mL}^{-1}\right)$, respectively to prevent a limitation in the PMO reduction step. As electron donor for $\mathrm{CDH}$ $500 \mu \mathrm{M}$ cellobiose was used. When ascorbate was used as reductant, it was added to a final concentration of $30 \mu \mathrm{M}$ and enzyme assays were started by mixing $20 \mu \mathrm{L}$ of the respective PMO with $180 \mu \mathrm{L}$ of the ready-made assay solution containing $30 \mu \mathrm{M}$ ascorbate, $50 \mu \mathrm{M}$ Amplex Red and 7.14 $\mathrm{U} \mathrm{mL}^{-1}$ peroxidase in 96-well plate wells. In reference experiments without PMO the background signal $\left(\mathrm{H}_{2} \mathrm{O}_{2}\right.$ production by $\left.\mathrm{CDH}\right)$ was measured and subtracted from the assays. When $\mathrm{CDH}$ was used as reductant, the PMO assays were started by mixing $20 \mu \mathrm{L}$ of sample solution and $20 \mu \mathrm{L} \mathrm{CDH}$ solution with $160 \mu \mathrm{L}$ of the reaction mix containing cellobiose, Amplex Red and peroxidase. Initial fluorescence scans of resorufin showed highest signal intensities and lowest interference with matrix compounds when using an excitation wavelength of $569 \mathrm{~nm}$ and an emission wavelength of $585 \mathrm{~nm}$ for the selected conditions. The stoichiometry of $\mathrm{H}_{2} \mathrm{O}_{2}$ conversion to resorufin formation is 1:1. By using a high concentration of Amplex Red $(50 \mu \mathrm{M})$ the linearity of the detection reaction was ensured and the molar ratio of Amplex Red: $\mathrm{H}_{2} \mathrm{O}_{2}$ was always greater than 50:1 [22]. The $\mathrm{H}_{2} \mathrm{O}_{2}$ concentration in the assays was far below $1 \mu \mathrm{M}$, which leads to a linear concentration/activity response of horseradish peroxidase, which has a $\mathrm{K}_{\mathrm{M}}$ for $\mathrm{H}_{2} \mathrm{O}_{2}$ of $1.55 \mu \mathrm{M}$. The high final activity of horseradish peroxidase $\left(7.14 \mathrm{U} \mathrm{mL}^{-1}\right)$ assures a fast conversion of the formed $\mathrm{H}_{2} \mathrm{O}_{2}$ and prevents the final reaction to be rate limiting. Additionally, it prevents the accumulation of $\mathrm{H}_{2} \mathrm{O}_{2}$, which could have detrimental effects on enzyme stability in the assay. The stability of resorufin fluorescence under these conditions was tested by addition of varying concentrations of hydrogen peroxide $(0.1-5 \mu \mathrm{M})$ to the assay. A stable signal that remained constant throughout the measured period of 45 minutes was observed and maximum signal intensity was reached already during the mixing period before starting the assay. A linear relation between fluorescence and $\mathrm{H}_{2} \mathrm{O}_{2}$ concentrations in the range of $0.1-2 \mu \mathrm{M} \mathrm{H}_{2} \mathrm{O}_{2}$ was observed and the slope (28450 counts $\mu \mathrm{mol}^{-1}$ ) was used for the calculation of an enzyme factor to convert the fluorimeters readout (counts $\mathrm{min}^{-1}$ ), into enzyme activity. PMO activity was defined as one $\mu \mathrm{mol} \mathrm{H}_{2} \mathrm{O}_{2}$ generated per minute under the defined assay conditions.

\section{Construction of pmo expression vectors for $P$. pastoris}

The synthetic pmo genes were digested with the restriction enzymes BstBI and $\mathrm{XbaI}$ and ligated into the equally treated vector pPICZ $\alpha$ A using the Rapid DNA Ligation Kit from Fermentas. The procedures resulted in plasmids carrying genes encoding proteins with their native signal sequences cloned under the control of the methanol inducible AOX1 promoter. C-terminal tags for purification or antibody detection were omitted. The plasmids were linearized with the restriction enzyme SacI and transformed into electro-competent P. pastoris cells. Transformants were grown on YPD plates $\left(10 \mathrm{~g} \mathrm{~L}^{-1}\right.$ yeast extract, $20 \mathrm{~g} \mathrm{~L}^{-1}$ peptone, $10 \mathrm{~g} \mathrm{~L}^{-1}$ glucose and $15 \mathrm{~g} \mathrm{~L}^{-1}$ agar) containing $100 \mathrm{mg} \mathrm{L}^{-1}$ zeocin.

\section{Enzyme production and purification}

The enzymes were produced in a 7-L bioreactor (MBR) with a starting volume of $3 \mathrm{~L}$ Basal Salts Medium $\left(21 \mathrm{~mL} \mathrm{~L}^{-1} \mathrm{H}_{3} \mathrm{PO}_{4}\right.$ (85\%); $0.93 \mathrm{~g} \mathrm{~L}^{-1} \mathrm{CaSO}_{4} \cdot 2 \mathrm{H}_{2} \mathrm{O}$; $14.9 \mathrm{~g} \mathrm{~L}^{-1} \mathrm{MgSO}_{4} \cdot 7 \mathrm{H}_{2} \mathrm{O} ; 18.2 \mathrm{~g} \mathrm{~L}^{-1} \mathrm{~K}_{2} \mathrm{SO}_{4} ; 4.13 \mathrm{~g} \mathrm{~L}^{-1}$ $\mathrm{KOH} ; 4 \%$ (v/v) glycerol) supplemented with $4.35 \mathrm{~mL} \mathrm{~L}^{-1}$ $\mathrm{PTM}_{1}$ trace salts (Invitrogen), $1 \mathrm{~mL}$ Antifoam 204 (Sigma) and $0.1 \mathrm{mM} \mathrm{CuSO}_{4}$. After sterilization, the $\mathrm{pH}$ of the medium was adjusted to $\mathrm{pH} 5.0$ with $28 \%$ ammonium hydroxide and maintained at this level throughout the entire fermentation process. The fermentations were started by adding $400 \mathrm{~mL}$ preculture grown on YPD medium in 1-L baffled shaking flasks at $125 \mathrm{rpm}$ and $30^{\circ} \mathrm{C}$ overnight. The cultivations were performed according to the Pichia Fermentation Process Guidelines of Invitrogen with some alterations. After depletion of glycerol in the batch medium the fed-batch phase was started with a constant feed of $36 \mathrm{~mL} \mathrm{~h}^{-1} 50 \%$ glycerol containing $12 \mathrm{~mL} \mathrm{~L}^{-1} \mathrm{PTM}_{1}$ trace salts overnight to increase biomass. For induction the feed was switched to $100 \%$ methanol containing $12 \mathrm{~mL} \mathrm{~L}^{-1} \mathrm{PTM}_{1}$ trace salts at an initial feed rate of $12 \mathrm{~mL} \mathrm{~h}^{-1}$ until the culture was fully adapted to methanol. Subsequently the feed rate was adjusted to keep the dissolved oxygen saturation constant at $4 \%$ at a constant air supply of $6 \mathrm{~L} \mathrm{~min}^{-1}$ and a stirrer speed of $800 \mathrm{rpm}$. After induction the cultivation temperature was reduced to $25^{\circ} \mathrm{C}$. Samples were taken regularly and wet biomass, protein concentration and PMO activity were measured.

The fermentation broth was centrifuged at $6400 \times \mathrm{g}$ and $4^{\circ} \mathrm{C}$ for $30 \mathrm{~min}$, and ammonium sulphate was slowly added to the clear culture supernatant to give a $30 \%$ 
saturated solution. Precipitate was removed by centrifugation $\left(6400 \times \mathrm{g}\right.$; $20 \mathrm{~min}$ at $\left.4^{\circ} \mathrm{C}\right)$ and the clear supernatant was loaded onto a 600-mL PHE-Sepharose Fast Flow column (chromatographic equipment and materials from GE Healthcare Biosciences) equilibrated with a $25 \mathrm{mM}$ sodium acetate buffer, $\mathrm{pH}$ 5.0, containing 30\% ammonium sulphate saturation. Proteins were eluted within a linear gradient from 30 to $0 \%$ ammonium sulphate within 3 column volumes and fractions were collected. Fractions containing the respective PMO were pooled and diafiltered with a hollow fiber cross-flow module (Microza UF module SLP-1053, 10 kDa cut-off, Pall Corporation). The diafiltered pools (conductivity $<1.4 \mathrm{mS} \mathrm{cm}^{-1}$ ) were applied to a $20-\mathrm{mL}$ column packed with Q15-Source equilibrated with $20 \mathrm{mM}$ TRIS/HCl buffer, $\mathrm{pH}$ 8.0. The flow-throughs were collected and contained the PMO enzymes. The solutions were concentrated, first by diafiltration with a Vivaflow cross-flow module (Millipore, cut-off $10 \mathrm{kDa}$ ) and subsequently by centrifugation in Amicon centrifugation tubes (Millipore, cut-off $10 \mathrm{kDa}, 3200 \mathrm{x} \mathrm{g}, 15 \mathrm{~min}$ at $4^{\circ} \mathrm{C}$ ). Size exclusion chromatography was done with a Superdex 75 column (Pharmacia Biotech) equilibrated with $20 \mathrm{mM}$ TRIS/HCl, pH 8.0 buffer. Fractions containing pure PMO enzyme were pooled and stored at $4^{\circ} \mathrm{C}$.

\section{Measurement of cellulolytic activity of PMOs}

Microcrystalline cellulose was incubated with the PMOs and analyzed for soluble cello-oligosaccharides. The cellulose concentration in $50 \mathrm{mM}$ sodium phosphate buffer, pH 6.0 was $25 \mathrm{mg} \mathrm{mL}^{-1}$ and PMOs were employed at a concentration of $5 \mathrm{mg} \mathrm{g}^{-1}$ cellulose. CDH IIA was used as reductant for PMO at a concentration of $2 \mathrm{mg} \mathrm{g}^{-1}$; cellulose and lactose $(200 \mu \mathrm{M})$ were used as electron donors for $\mathrm{CDH}$. A total volume of $400 \mu \mathrm{L}$ was incubated at $30^{\circ} \mathrm{C}$ for 72 hours on a shaking incubator operated at $320 \mathrm{rpm}$ and $90 \%$ humidity. The reaction tubes were sealed with an air permeable membrane to ensure continuous oxygen supply. Negative controls without $\mathrm{CDH}$ IIA and PMOs were performed under the same conditions. After incubation the samples were heated to $95^{\circ} \mathrm{C}$ for $10 \mathrm{~min}$ and protein precipitate and remaining cellulose was removed by centrifugation. Released cellooligosaccharides were detected by HPLC using a CarboPac PA100 Carbohydrate Column equipped with a guard column and an ED40 electrochemical detector (all equipment from DIONEX). The column was equilibrated with $150 \mathrm{mM} \mathrm{NaOH}$ (solution A) and reaction products were eluted by a linear gradient from 0 to $30 \%$ solution B (500 $\mathrm{mM}$ sodium carbonate in solution A) within 25 minutes at a flow rate of $0.5 \mathrm{~mL} \mathrm{~min}^{-1}$. The column was washed with $100 \%$ solution $\mathrm{A}$ for 5 minutes and re-equilibrated for 13 minutes with solution B before starting the next run.

\section{Protein concentrations}

Protein contents of crude preparations or partially purified fractions were determined by the dye-binding method of Bradford using a pre-fabricated assay (Biorad Laboratories) and BSA as calibration standard. Protein concentrations of purified samples were measured based on their extinction coefficient at $280 \mathrm{~nm}$ (PMO) or $420 \mathrm{~nm}$ (CDH IIA).

\section{Spectral characterization}

Spectra of homogenously purified PMO enzymes were recorded with a Hitachi U-3000 spectrophotometer at room temperature. Appropriately diluted enzymes (Abs $\sim 1$ at $280 \mathrm{~nm}$ ) were measured from 250 to $800 \mathrm{~nm}$ at a scan speed of $60 \mathrm{~nm} \mathrm{~min}{ }^{-1}$. To assess the extinction coefficients of the type- 2 copper sites, spectra of concentrated enzymes were recorded from 450 to $800 \mathrm{~nm}$ at a scan speed of $30 \mathrm{~nm} \mathrm{~min}{ }^{-1}$. Spectra of reduced species were obtained by addition of an excess of ascorbate to the cuvette. The molar absorption coefficients at $280 \mathrm{~nm}$ for all enzymes were calculated using the mature amino acid sequence and the program ProtParam (http://web. expasy.org/protparam/).

\section{Deglycosylation}

PMO enzymes $\left(1.5 \mathrm{mg} \mathrm{mL}^{-1}, 20 \mu \mathrm{L}\right)$ were treated with PNGase F under denaturing conditions. The enzymes were mixed with $2 \mu \mathrm{L}$ of glycoprotein denaturing buffer (80.5\% sodium dodecylsulfate, $1 \%$ mercaptoethanol) and incubated at $99^{\circ} \mathrm{C}$ for $10 \mathrm{~min}$. Then, $4 \mu \mathrm{L}$ of $0.5 \mathrm{M}$ sodium phosphate buffer, $\mathrm{pH} 7.5,4 \mu \mathrm{L}$ of nonylphenol $(40 \%)$ and $1 \mu \mathrm{L}$ of PNGase $\mathrm{F}$ were added to the reaction mix and incubated at $37^{\circ} \mathrm{C}$ for 1 hour. Glycosylation sequons were predicted using the servers NetNGlyc 1.0 (http://www.cbs.dtu.dk/services/NetNGlyc/) and NetOGlyc 3.1 (http://www.cbs.dtu.dk/services/NetOGlyc/).

\section{Gel electrophoresis}

Mini-PROTEAN TGX precast gels (Bio-Rad Laboratories) with a gradient from $4-20 \%$ were used for SDS-PAGE analysis of purified enzymes and fermentation supernatants. Protein bands were visualized by staining with Bio-Safe Coomassie, and unstained Precision Plus Protein Standard was used for mass determination. All procedures were done according to the manufacturer's recommendations (Bio-Rad Laboratories). Three independent gels were used for molecular mass determination of PMO enzymes.

\section{Differential scanning calorimetry}

Thermodynamic stabilities of PMO enzymes were measured by differential scanning calorimetry (DSC) using a MicroCal VP-DSC instrument with an autosampler (MicroCal, Northampton, MA). Enzyme concentrations 
were adjusted to $1 \mathrm{mg} \mathrm{mL} \mathrm{m}^{-1}$ based on their molar extinction coefficients at $280 \mathrm{~nm}$. All measurements were carried out in $100 \mathrm{mM}$ phosphate buffer, $\mathrm{pH}$ 6.0. A linear temperature ramp from 20 to $100^{\circ} \mathrm{C}$ was applied at a scan rate of $1 \mathrm{~K}$ per min. Prior to all measurements, samples were degassed by continuous stirring in vacuo for $15 \mathrm{~min}$. Obtained sample thermograms were corrected for the calorimeter baseline by subtracting a buffer blank that was scanned in the reference chamber. Transition midpoint temperatures $\left(T_{\mathrm{M}}\right)$ of the enzymes were determined from the peak maximum of transition using the Origin 7.5 software (Origin Lab Corporation, Northampton, MA).

\section{Additional files}

\section{Additional file 1: Stability of resorufin fluorescence at various} concentrations.

Additional file 2: Background $\mathrm{H}_{2} \mathrm{O}_{2}$ production by Pichia fermentation culture supernatants and permeates.

Additional file 3: Amino acid sequences of PMO-01867, PMO-02916, PMO-03328 and PMO-08760. Signal peptides are highlighted in green, putative $\mathrm{N}$-glycosylation sites in yellow and putative O-glycosylation sites in red. CBMs are underlined.

Additional file 4: DSC of PMO-01867, PMO-02916, PMO-03328 and PMO-08760.

Additional file 5: Codon optimized sequences of pmo-01867, pmo-02916, pmo-03328 and pmo-08760.

\section{Abbreviations}

$\mathrm{CDH}$ : Cellobiose dehydrogenase; CMC: Carboxymethyl cellulose GH61: Family 61 glycoside hydrolase; PASC: Phosphoric acid swollen cellulose; PMO: Polysaccharide monooxygenase.

Competing interests

The authors declare that they have no competing interests.

\section{Authors' contributions}

RK prepared the $P$. pastoris expression strains. RK and DB carried out the fermentation and purification of the PMOs. RL and DK developed the enzyme assay. DK performed the enzyme characterization and wrote part of the manuscript. RK coordinated the experiments and drafted the manuscript. $\mathrm{DH}$ and $\mathrm{RL}$ initiated, designed and coordinated the study and reviewed the manuscript. All authors have read and approved the final manuscript.

\section{Acknowledgements}

This work has been supported by the doctoral program "BioTop Biomolecular Technology of Proteins" (FWF W1224) of the Austrian Science Fund FWF.

Received: 31 July 2012 Accepted: 22 October 2012

Published: 26 October 2012

\section{References}

1. Horn SJ, Vaaje-Kolstad G, Westereng B, Eijsink VG: Novel enzymes for the degradation of cellulose. Biotechnology for Biofuels 2012, 5:45.

2. Langston JA, Shaghasi T, Abbate E, Xu F, Vlasenko E, Sweeney MD: Oxidoreductive cellulose depolymerization by the enzymes cellobiose dehydrogenase and glycoside hydrolase 61. App/ Environ Microbiol 2011, 77:7007-7015.

3. Phillips CM, Beeson WT, Cate JH, Marletta MA: Cellobiose dehydrogenase and a copper-dependent polysaccharide monooxygenase potentiate cellulose degradation by Neurospora crassa. ACS Chem Biol 2011 6:1399-1406.

4. Quinlan RJ, Sweeney MD, Lo Leggio L, Otten H, Poulsen J-CN, Johansen KS, Krogh KBRM, Jørgensen Cl, Tovborg M, Anthonsen A, Tryfona T, Walter CP, Dupree P, Xu F, Davies GJ, Walton PH: Insights into the oxidative degradation of cellulose by a copper metalloenzyme that exploits biomass components. Proc Natl Acad Sci USA 2011, 108:15079-15084

5. Forsberg Z, Vaaje-kolstad G, Westereng B, Bunsæ AC, Stenstrøm Y, Mackenzie A, Sørlie M, Horn SJ, Eijsink VGH: Cleavage of cellulose by a CBM33 protein. Protein Sci 2011, 20:1479-1483.

6. Harris PV, Welner D, McFarland KC, Re E, Navarro Poulsen J-C, Brown K, Salbo R, Ding H, Vlasenko E, Merino S, Xu F, Cherry J, Larsen S, Lo Leggio L: Stimulation of lignocellulosic biomass hydrolysis by proteins of glycoside hydrolase family 61: Structure and function of a large, enigmatic family. Biochemistry 2010, 49:3305-3316.

7. Dimarogona M, Topakas E, Olsson L, Christakopoulos P: Lignin boosts the cellulase performance of a GH-61 enzyme from Sporotrichum thermophile. Bioresour Technol 2012, 110:480-487.

8. Beeson WT, Phillips CM, Cate JHD, Marletta MA: Oxidative cleavage of cellulose by fungal copper-dependent polysaccharide monooxygenases. J Am Chem Soc 2012, 134:890-892.

9. Berka RM, Grigoriev IV, Otillar R, Salamov A, Grimwood J, Reid I, Ishmael N, John T, Darmond C, Moisan M-C, Henrissat B, Coutinho PM, Lombard V, Natvig DO, Lindquist E, Schmutz J, Lucas S, Harris P, Powlowski J, Bellemare A, Taylor D, Butler G, de Vries RP, Allijn IE, van den Brink J, Ushinsky S, Storms R, Powell AJ, Paulsen IT, Elbourne LDH, Baker SE, Magnuson J, LaBoissiere S, Clutterbuck AJ, Martinez D, Wogulis M, de Leon AL, Rey MW, Tsang A: Comparative genomic analysis of the thermophilic biomass-degrading fungi Myceliophthora thermophila and Thielavia terrestris. Nat Biotechnol 2011, 29:922-927.

10. Eastwood DC, Floudas D, Binder M, Majcherczyk A, Schneider P, Aerts A Asiegbu FO, Baker SE, Barry K, Bendiksby M, Blumentritt M, Coutinho PM, Cullen D, de Vries RP, Gathman A, Goodell B, Henrissat B, Ihrmark K, Kauserud H, Kohler A, LaButti K, Lapidus A, Lavin JL, Lee Y-H, Lindquist E, Lilly W, Lucas S, Morin E, Murat C, Oguiza JA, Park J, Pisabarro AG, Riley R, Rosling A, Salamov A, Schmidt O, Schmutz J, Skrede I, Stenlid J, Wiebenga A, Xie X, Kües U, Hibbett DS, Hoffmeister D, Högberg N, Martin F, Grigoriev IV, Watkinson SC: The plant cell wall-decomposing machinery underlies the functional diversity of forest fungi. Science 2011, 333:762-765.

11. Tian C, Beeson WT, lavarone AT, Sun J, Marletta MA, Cate JHD, Glass NL: Systems analysis of plant cell wall degradation by the model filamentous fungus Neurospora crassa. PNAS 2009, 106:22157-22162.

12. Westereng $B$, Ishida T, Vaaje-Kolstad G, Wu M, Eijsink VGH, Igarashi K, Samejima M, Ståhlberg J, Horn SJ, Sandgren M: The putative endoglucanase PcGH61D from Phanerochaete chrysosporium is a metal-dependent oxidative enzyme that cleaves cellulose. PLoS One 2011, 6:e27807.

13. Koseki T, Mese $Y$, Fushinobu S, Masaki K, Fujii T, Ito K, Shiono Y, Murayama T, lefuji $\mathrm{H}$ : Biochemical characterization of a glycoside hydrolase family 61 endoglucanase from Aspergillus kawachii. Appl Microbiol Biotechnol 2007, 77:1279-1285

14. Vaaje-Kolstad G, Westereng B, Horn SJ, Liu Z, Zhai H, Sørlie M, Eijsink VGH: An oxidative enzyme boosting the enzymatic conversion of recalcitrant polysaccharides. Science 2010, 330:219-222.

15. Li X, Beeson WT, Phillips CM, Marletta MA, Cate JHD: Structural basis for substrate targeting and catalysis by fungal polysaccharide monooxygenases. Structure 2012, 20:1051-1061.

16. Zhou M, Diwu Z, Panchuk-Voloshina N, Haugland RP: A stable nonfluorescent derivative of resorufin for the fluorometric determination of trace hydrogen peroxide: Applications in detecting the activity of phagocyte NADPH oxidase and other oxidases. Anal Biochem 1997, 253:162-168.

17. Phillips CM, lavarone AT, Marletta MA: Quantitative proteomic approach for cellulose degradation by Neurospora crassa. J Proteome Res 2011, 10:4177-4185

18. Sygmund C, Kracher D, Scheiblbrandner S, Zahma K, Felice AKG, Harreither W, Kittl R, Ludwig R: Characterization of the two Neurospora crassa cellobiose dehydrogenases and their connection to oxidative cellulose degradation. Appl Environ Microbiol 2012, 78:6161-6171.

19. Ettinger MJ: Spectral properties of "non-blue" cupric copper in proteins. Circular dichroism and optical spectra of galactose oxidase. Biochemistry 1974, 13:1242-1247. 
20. Wright $\mathrm{C}$, Sykes AG: Interconversion of $\mathrm{Cu}^{\prime}$ and $\mathrm{Cu}^{\prime \prime}$ forms of galactose oxidase: comparison of reduction potentials. J Inorg Biochem 2001, 85:237-243.

21. Radford A: Glycosyl hydrolase genes and enzymes of Neurospora crassa. Fungal Genet. Newsletter 2006, 53:12-14.

22. Seong GH, Heo J, Crooks RM: Measurement of enzyme kinetics using a continuous-flow microfluidic system. Anal Chem 2003, 75:3161-3167.

doi:10.1186/1754-6834-5-79

Cite this article as: Kittl et al:: Production of four Neurospora crassa lytic polysaccharide monooxygenases in Pichia pastoris monitored by a fluorimetric assay. Biotechnology for Biofuels 2012 5:79.

\section{Submit your next manuscript to BioMed Central and take full advantage of:}

- Convenient online submission

- Thorough peer review

- No space constraints or color figure charges

- Immediate publication on acceptance

- Inclusion in PubMed, CAS, Scopus and Google Scholar

- Research which is freely available for redistribution 